\title{
Combining Ability and Gene Action Studies for Grain Yield and its Components in Pearl Millet [Pennisetum glaucum (L.) R. Br.]
}

\author{
S. H. Patil", P. B. Wadikar, S. L. Waghmode and R. G. Tathe \\ Department of Agricultural Botany, College of Agriculture Latur, Vasantrao Naik \\ Marathwada Krishi Vidypeeth, Parbhani, (M.S), India \\ *Corresponding author
}

A B S T R A C T

Keywords

Combining ability, Gene action, L x T, Pearl millet

Article Info

Accepted:

15 December 2020

Available Online:

10 January 2021
Pearl millet (Pennisetum glaucum (L.) R. Br.) is commonly known as bajra, cat-tail millet, or bulrush millet in different parts of the world. It is predominantly grown as a staple food grain and source of feed and fodder. In present study, 60 hybrids were produced by crossing four male sterile lines with ten diverse inbred lines in $\mathrm{L}$ x $\mathrm{T}$ mating design and analyzed in RBD with two replications to study combining ability effects. The analysis of variance for combining ability revealed that mean squares due to parents and crosses were significant for all characters studied indicated significant differences for all characters. However, $\delta^{2}$ gca $/ \delta^{2}$ sca ratio depicted preponderance of non additive gene action for all the characters except days to $50 \%$ flowering, days to maturity, earhead length and earhead girth, thereby suggesting the importance of both additive and non additive gene effects. Among the parents S-19/12, S-19/11, S-19/13, S-16/769 A and DHLB-23 A were good general combiner for grain yield per plant. While, in case of hybrids, S-16/704 A x S19/12 followed by S-16/760 A x S-19/05, DHLB-23 A x S-19/04 were good specific combiners for grain yield per plant.

\section{Introduction}

Pearl millet is the most important cereal crop of tropical and subtropical region of the world. In fact, Pearl millet is the only suitable and efficient crop for arid and semi-arid conditions because of its efficient utilization of soil moisture and higher level of heat tolerance than sorghum and maize. Pearl millet has balanced genetic load and show considerable inbreeding depression therefore, the varieties aimed to be developed in pearl millet should have heterozygous nature to be heterotic and at the same time homogenous constitution to be synchronous and uniformly productive. The quantum jump (from $303 \mathrm{~kg}$ to $850 \mathrm{~kg} / \mathrm{ha}$ ) in the productivity of pearl millet was possible mainly through development of hybrids by the utilization of cytoplasmic genetic male sterility system. Burton (1958) was the first to develop cytoplasmic male sterile line Tift $23 \mathrm{~A}$ bred at Tifton, Georgia, USA. This opened up a new field for hybrid seed production in Pearl millet. In India, first Pearl millet hybrid HB-1 was released in 1965 (Athwal, 1965). The 
utilization of diverse sources of male sterility was then felt necessary and work in this direction led to the identification of several alternative sources like, A1, A2, A3, A4, A5, etc. For the development of effective heterosis breeding programme in pearl millet, one needs to have information about genetic architecture and estimated prepotency of parents in hybrid combinations. Selection made on phenotypic performance alone does not lead to expected success in hybrid breeding. Therefore, a study on combining ability of parents is essential in choosing parents.

Many biometrical procedures have been developed to obtain information on combining ability. A line $\mathrm{x}$ tester analysis is one among them which is widely used to study combining ability of the parents to be chosen for heterosis breeding. It also provides a guideline to determine the value of source populations and appropriate procedures to use in crop improvement programme.

\section{Materials and Methods}

The experimental material comprised of four male sterile lines S-16/760A, S-16/769A, S16/704A, DHLB-23A and ten restorers $S$ 19/03, S-19/04, S-19/05, S-19/08, S-19/09, S19/10, S-19/11, S-19/12, S-19/13, S-19/14 with two checks Aadishakti and AHB 1200 (Fe). Crosses were done in line $\mathrm{x}$ tester fashion to obtain 40 hybrids. All experimental material evaluated in randomized block design with two replication during Kharif 2019. Five competitive plants were selected randomly from each treatment in each replication for grain yield per plant and its component traits viz., Days to $50 \%$ flowering, Days to maturity, Number of effective tillers per plant, Plant height, Earhead length, Earhead girth, 1000 seed weight, Grain yield per plant, Fodder yield per plant, Harvest index and averages were worked out.
Combining ability analysis and the testing of significance of different genotypes was based on the procedure given by kempthorne (1957).

\section{Results and Discussion}

To test the significance of differences among the treatments analysis of variance of mean was carried out. The analysis of variance for combining ability (Table 1.) revealed that mean sum of square due to parents and crosses exhibited highly significant differences for all the characters indicating existence of sufficient amount of variability among material studied. Parent $v s$ crosses differed significantly for all the characters (except plant height). Such variations in parent material have been reported earlier by Naik et al., (1996), Lakshmana et al., (2011) and Solanki et al., (2017).

However, the estimates of both $\delta^{2}$ gca and $\delta^{2}$ sca (variance due to GCA and variance due to SCA) were significant for all characters revealing that both additive and non-additive gene action were involved in expression of these traits. Almost similar trends of involvement of both additive and non-additive gene actions have been earlier reported by Patel et al., (2016). The ratio of $\left(\delta^{2} \mathrm{gca} / \delta^{2} \mathrm{sca}\right)$ was found less than unity for all characters (except days to $50 \%$ flowering, days to maturity, earhead length and earhead girth) indicated preponderance of non additive gene action for the characters namely number of effective tillers per plant, plant height, 1000 seed weight, grain yield per plant, fodder yield per plant, harvest index. Since non additive gene action is involved for inheritance of grain yield, heterosis breeding would be most effective approach to improve the character. Pearl millet is cross pollinated crop; hence heterosis can be utilized for development of hybrids. 
Table.1 Analysis of variance of combining ability for different characters in pearl millet

\begin{tabular}{|c|c|c|c|c|c|c|c|c|c|c|c|}
\hline Source of variance & d.f & DF & DM & NET & PH & EL & EG & TW & GYP & FY & HI \\
\hline Replication & 1 & 0.59 & 0.59 & 0.018 & 22.41 & 0.06 & 0.08 & 0.92 & 5.24 & 0.78 & 0.12 \\
\hline Parents & 13 & $28.18 * *$ & $23.21 * *$ & $0.09 * *$ & $1514.68 * *$ & $14.24 * *$ & $1.18 * *$ & $3.31 * *$ & $73.34 * *$ & $604.73 * *$ & $76.94 * *$ \\
\hline Lines & 3 & $4.00 *$ & $9.83 * *$ & $0.12 * *$ & $441.5 * *$ & $3.65 * *$ & $0.62 * *$ & 0.36 & $33.97 *$ & 76.35 & 5.42 \\
\hline Testers & 9 & $12.55 * *$ & $8.53 * *$ & $0.08 * *$ & $309.98 * *$ & $5.66 * *$ & $1.49 * *$ & $4.64 * *$ & $94.19 * *$ & $673.61 * *$ & $85.76 * *$ \\
\hline Crosses & 39 & $13.84 * *$ & $26.29 * *$ & $0.23 * *$ & $307.86 * *$ & $5.59 * *$ & $0.93 * *$ & $4.11 * *$ & $162.03 * *$ & $474.90 * *$ & $42.23 * *$ \\
\hline Parent vs Crosses & 1 & $150.40 * *$ & $105.33 * *$ & $1.94 * *$ & 70.38 & $24.99 * *$ & $17.22 * *$ & $306.08 * *$ & $9381.48 * *$ & $3744.08 * *$ & $1496.54 * *$ \\
\hline$\delta 2$ gca & & $2.1474 * *$ & $5.426 * *$ & $0.0304 * *$ & $50.208 * *$ & $1.535 * *$ & $0.113 * *$ & $0.532 * *$ & $23.95 * *$ & $76.887 * *$ & $5.265 * *$ \\
\hline$\delta 2$ sca & & $1.6004 * *$ & $2.430 * *$ & $0.0569 * *$ & $84.366 * *$ & $0.851 * *$ & $0.113 * *$ & $1.336 * *$ & $43.76 * *$ & $78.169 * *$ & $7.772 * *$ \\
\hline$\delta 2$ gca $/ \delta 2$ sca & & 1.3418 & 2.2324 & 0.5344 & 0.5951 & 1.8028 & 1.0014 & 0.3988 & 0.5473 & 0.9836 & 0.6775 \\
\hline Error & 53 & 1.34 & 1.95 & 0.005 & 38.38 & 0.67 & 0.14 & 0.30 & 8.30 & 46.03 & 2.64 \\
\hline
\end{tabular}

$*$ and $* *$ Significant at 5 and 1 per cent level, respectively.

Where,

$\mathrm{DF}=$ Days to $50 \%$ flowering $\quad \mathrm{PH}=$ Plant height $(\mathrm{cm}) \quad \mathrm{TW}=1000$-seed weight $(\mathrm{g}) \mathrm{HI}=$ Harvest index $(\%)$

$\mathrm{DM}=$ Days to maturity $\mathrm{EL}=$ Earhead length $\quad \mathrm{GYP}=$ Grain yield per plant $(\mathrm{g})$

$\mathrm{NET}=$ No. of effective tillers per plant EG = Earhead girth $\quad$ FY = Fodder yield per plant $(\mathrm{g})$

Table.2 Estimates of general and specific combining ability effects for different characters in pearl millet

\begin{tabular}{|c|c|c|c|c|c|c|c|c|c|c|c|}
\hline Sr. No. & Parents/ Crosses & DF & DM & NET & PH & EL & EG & $1000 \mathrm{SW}$ & GYP & FY & HI \\
\hline \multicolumn{12}{|l|}{ Lines } \\
\hline 1 & S-16/760 A & $-1.150 * *$ & $-2.675 * *$ & $-0.059 * *$ & $-8.035 * *$ & $-0.976 * *$ & $-0.133 * *$ & $0.180 * *$ & $-6.165 * *$ & $-11.040 * *$ & $1.516 * *$ \\
\hline 2 & S-16/769 A & $1.050 * *$ & $1.325 * *$ & $-0.009 * *$ & $-1.375 * *$ & $1.324 * *$ & $-0.166 * *$ & $0.715 * *$ & $3.655 * *$ & 2.570 & $0.672 *$ \\
\hline 3 & S-16/704 A & $0.850 * *$ & $2.125 * *$ & $-0.109 * *$ & $10.295 *$ & $1.124 * *$ & $0.272 * *$ & $0.074 *$ & $-0.685 * *$ & 1.560 & $-1.493 * *$ \\
\hline 4 & DHLB-23 A & $-0.750 * *$ & $-0.775 * *$ & $0.176 * *$ & $-0.885 * *$ & $-1.471 * *$ & 0.028 & $-0.970 * *$ & $3.195 *$ & 6.910 & $-0.695 * *$ \\
\hline \multicolumn{12}{|l|}{ Testers } \\
\hline 5 & S-19/03 & $1.300 * *$ & $2.325 * *$ & $0.176 * *$ & 8.990 & 0.261 & $-0.715 * *$ & $0.402 * *$ & $-1.710 * *$ & 15.850 & $-6.124 * *$ \\
\hline 6 & S-19/04 & 0.300 & 0.825 & $0.251 * *$ & 1.315 & $-0.526 * *$ & $-0.589 * *$ & $-0.528 * *$ & $-1.560 * *$ & 9.450 & $-4.049 * *$ \\
\hline 7 & S-19/05 & $-1.200 * *$ & $-1.425 * *$ & $0.376 * *$ & 0.765 & $-0.689 * *$ & $-0.887 * *$ & $-1.536 * *$ & $-2.985 * *$ & 10.525 & $-5.326 * *$ \\
\hline 8 & S-19/08 & $-0.450 * *$ & $-0.675 * *$ & $-0.099 * *$ & $-2.860 * *$ & 0.011 & 0.072 & $-0.733 * *$ & $-3.935 * *$ & $-9.950 * *$ & $1.989 *$ \\
\hline 9 & S-19/09 & $-3.450 * *$ & $-4.925 * *$ & $-0.574 * *$ & $-15.460 * *$ & $-0.814 * *$ & $0.195 * *$ & $-0.130 * *$ & $-12.460 * *$ & $-20.950 * *$ & 1.022 \\
\hline 10 & S-19/10 & $-3.700 * *$ & $-4.425 * *$ & 0.001 & $-3.210 * *$ & $-0.564 * *$ & $-0.244 * *$ & $-0.549 * *$ & 2.015 & $-9.950 * *$ & $4.463 * *$ \\
\hline 11 & S-19/11 & $1.050 *$ & $1.575 *$ & $-0.049 * *$ & 2.140 & $-0.001 * *$ & $0.359 * *$ & $0.854 * *$ & $5.990 *$ & 5.300 & 0.841 \\
\hline 12 & S-19/12 & $1.800 * *$ & $2.075 * *$ & $-0.124 * *$ & 2.215 & $0.424 *$ & $0.748 * *$ & $1.120 * *$ & $6.665 *$ & 6.350 & 0.910 \\
\hline 13 & S-19/13 & $2.050 * *$ & $2.075 * *$ & $0.139 * *$ & 2.965 & $1.199 * *$ & $0.512 * *$ & $0.401 * *$ & $5.990 *$ & $-5.175 * *$ & $4.250 * *$ \\
\hline 14 & S-19/14 & $2.300 * *$ & $2.575 * *$ & $-0.099 * *$ & 3.140 & $0.699 * *$ & $0.548 * *$ & $0.699 * *$ & 1.990 & $-1.450 * *$ & $2.023 *$ \\
\hline \multicolumn{12}{|l|}{ Crosses } \\
\hline 15 & 760 A x S-19/03 & -1.100 & -0.325 & $0.234 * *$ & 1.360 & -0.411 & 0.124 & 0.548 & $4.590 *$ & $11.340 *$ & $-2.350^{*}$ \\
\hline 16 & 760 A x S-19/04 & -0.100 & 0.175 & -0.041 & -2.765 & 0.426 & 0.131 & $1.078 * *$ & 2.640 & $15.140 * *$ & $-4.125 * *$ \\
\hline
\end{tabular}




\begin{tabular}{|c|c|c|c|c|c|c|c|c|c|c|c|}
\hline 17 & 760 A x S-19/05 & 0.400 & 0.425 & $-0.166 * *$ & 4.585 & -0.061 & 0.489 & $2.036 * *$ & $9.765 * *$ & 7.065 & 1.618 \\
\hline 18 & 760 A x S-19/08 & -1.350 & -1.325 & 0.009 & -2.290 & $-1.661 * *$ & -0.100 & 0.383 & 0.015 & -8.560 & $4.408 * *$ \\
\hline 19 & 760 A x S-19/09 & 0.650 & 0.925 & $0.184 * *$ & 2.510 & -0.136 & -0.252 & $-1.070 * *$ & 0.140 & 0.540 & -0.050 \\
\hline 20 & 760 A x S-19/10 & $2.900 * *$ & $3.425 * *$ & 0.009 & 7.060 & 1.064 & 0.231 & -0.501 & -0.035 & 6.640 & $-2.806 *$ \\
\hline 21 & 760 A x S-19/11 & 0.150 & 0.425 & -0.041 & 3.610 & $1.951 * *$ & 0.118 & $-0.804 *$ & -1.610 & -3.510 & -0.054 \\
\hline 22 & 760 A x S-19/12 & 0.400 & -0.075 & -0.066 & 0.335 & -0.374 & -0.114 & $-1.070 * *$ & $-7.485 * *$ & $-11.060 *$ & -0.108 \\
\hline 23 & 760 A x S-19/13 & -0.850 & -0.075 & $-0.129 *$ & 0.285 & -0.549 & -0.240 & $-1.731 * *$ & $-9.110 * *$ & -2.235 & $-3.818 * *$ \\
\hline Sr. No. & Parents/ Crosses & DF & DM & NET & PH & EL & EG & $1000 \mathrm{SW}$ & GYP & FY & HI \\
\hline 24 & 760 A x S-19/14 & -1.100 & $-3.575 * *$ & 0.009 & $-14.690 * *$ & -0.249 & -0.385 & $1.131 * *$ & 1.090 & $-15.360 * *$ & $7.284 * *$ \\
\hline 25 & 769 A x S-19/03 & -0.300 & -0.325 & 0.084 & $-11.200^{*}$ & -0.761 & $-0.909 * *$ & $-1.378 * *$ & $-7.73 * *$ & -6.770 & -1.581 \\
\hline 26 & 769 A x S-19/04 & $-2.300 * *$ & -0.825 & $0.309 * *$ & $-14.725 * *$ & $-1.974 * *$ & -0.549 & $-0.883 *$ & $-6.580 * *$ & -8.870 & -0.320 \\
\hline 27 & 769 A x S-19/05 & -0.800 & 0.425 & $-0.216 * *$ & -5.775 & -0.011 & 0.188 & $0.856 *$ & -2.055 & -7.945 & 1.847 \\
\hline 28 & 769 A x S-19/08 & 0.450 & 1.675 & $0.159 * *$ & -3.950 & 0.239 & -0.017 & 0.442 & 2.995 & 9.630 & -2.158 \\
\hline 29 & 769 A x S-19/09 & -1.550 & $-3.075 * *$ & 0.034 & $-10.150 *$ & -0.536 & 0.033 & 0.150 & 0.520 & 0.030 & 0.895 \\
\hline 30 & 769 A x S-19/10 & -1.300 & $-2.575 *$ & $-0.141 * *$ & -0.600 & 0.714 & 0.283 & 0.253 & 1.545 & -1.470 & 1.343 \\
\hline 31 & 769 A x S-19/11 & $2.950 * *$ & 1.425 & 0.009 & $10.850 *$ & 0.951 & 0.512 & $1.061 * *$ & $5.070 *$ & 5.380 & 0.510 \\
\hline 32 & 769 A x S-19/12 & 1.200 & 0.925 & $-0.216 * *$ & $12.775 * *$ & 0.876 & -0.065 & -0.215 & -2.705 & -3.070 & 0.271 \\
\hline 33 & 769 A x S-19/13 & 0.950 & 0.925 & $-0.279 * *$ & 8.025 & 0.151 & 0.327 & -0.072 & $7.070 * *$ & -1.245 & $3.591 * *$ \\
\hline 34 & 769 A x S-19/14 & 0.700 & 1.425 & $0.259 * *$ & $14.750 * *$ & 0.351 & 0.198 & -0.214 & 1.870 & $14.330 * *$ & $-4.397 * *$ \\
\hline 35 & 704 A x S-19/03 & -0.100 & -1.125 & -0.016 & -0.170 & -0.611 & 0.052 & $1.133 * *$ & -1.390 & 0.04 & 0.219 \\
\hline 36 & $704 \mathrm{~A} x \mathrm{~S}-19 / 04$ & -0.100 & -1.625 & $-0.191 * *$ & -2.695 & 0.026 & -0.189 & -0.412 & $-4.840 *$ & $-15.060 * *$ & $2.759 *$ \\
\hline 37 & 704 A x S-19/05 & 0.400 & 0.625 & $0.184 * *$ & -7.545 & 0.039 & -0.344 & $-2.133 * *$ & $-12.115^{* *}$ & $-12.135 *$ & $-2.754 *$ \\
\hline 38 & 704 A x S-19/08 & -0.350 & -1.125 & $-0.241 * *$ & 2.980 & 0.189 & -0.079 & $-1.532 * *$ & -3.265 & -3.960 & -0.419 \\
\hline 39 & 704 A x S-19/09 & 1.650 & $3.125 * *$ & $-0.166 * *$ & -1.320 & 0.464 & -0.154 & -0.074 & $-4.740 *$ & 0.640 & $-3.506 * *$ \\
\hline 40 & 704 A x S-19/10 & -1.100 & -0.375 & 0.059 & -1.770 & -0.336 & 0.112 & -0.221 & -0.315 & -1.960 & 1.178 \\
\hline 41 & 704 A x S-19/11 & $-1.850 *$ & -1.375 & $0.109 *$ & 0.680 & -1.049 & 0.247 & $1.397 * *$ & 3.010 & 8.990 & -0.831 \\
\hline 42 & 704 A x S-19/12 & -0.600 & -0.875 & $0.584 * *$ & 1.105 & 0.326 & 0.250 & 0.706 & $16.735 * *$ & $16.240 * *$ & $2.400 *$ \\
\hline 43 & 704 A x S-19/13 & 1.150 & 1.125 & $0.121 *$ & 0.855 & 0.251 & -0.126 & 0.364 & $8.410 * *$ & $9.765 *$ & 0.990 \\
\hline 44 & 704 A x S-19/14 & 0.900 & 1.625 & $-0.441 * *$ & 7.880 & 0.701 & 0.231 & 0.772 & -1.490 & -2.560 & -0.037 \\
\hline 45 & 23 A x S-19/03 & 1.500 & 1.775 & $-0.301 * *$ & $10.010 *$ & $1.784 * *$ & $0.733 *$ & -0.303 & $4.530 *$ & -4.610 & $3.711 * *$ \\
\hline 46 & $23 \mathrm{~A} \times \mathrm{S}-19 / 04$ & $2.500 * *$ & $2.275 *$ & -0.076 & $20.185 * *$ & $1.521 *$ & $0.607 *$ & 0.217 & $8.780 * *$ & 8.790 & 1.686 \\
\hline 47 & $23 \mathrm{~A} \times \mathrm{S}-19 / 05$ & $-1.200 * *$ & -1.475 & $0.199 * *$ & 8.735 & 0.034 & -0.332 & -0.759 & $4.405 *$ & $13.015 * *$ & -0.712 \\
\hline 48 & 23 A x S-19/08 & 1.250 & 0.775 & 0.074 & 3.260 & $1.234 *$ & 0.197 & 0.707 & 0.255 & 2.890 & -1.832 \\
\hline 49 & 23 A x S-19/09 & -0.750 & -0.975 & -0.051 & $8.960 *$ & 0.209 & 0.373 & $0.995 *$ & 4.080 & -1.210 & $2.661 *$ \\
\hline $\mathbf{5 0}$ & 23 A x S-19/10 & -0.500 & -0.475 & 0.074 & -4.690 & $-1.441 *$ & $-0.625 *$ & 0.468 & -1.195 & -3.210 & 0.285 \\
\hline Sr. No. & Parents/ Crosses & DF & DM & NET & PH & EL & EG & $1000 \mathrm{SW}$ & GYP & FY & HI \\
\hline 51 & 23 A x S-19/11 & -1.250 & -0.475 & -0.076 & $-15.140 * *$ & $-1.854 * *$ & $-0.877 * *$ & $-1.654 * *$ & $-6.470 * *$ & $-10.860 *$ & 0.376 \\
\hline 52 & 23 A x S-19/12 & -1.000 & 0.025 & $-0.301 * *$ & $-14.215 * *$ & -0.829 & -0.071 & 0.580 & $-6.545 * *$ & -2.110 & $-2.563 *$ \\
\hline 53 & 23 A x S-19/13 & -1.250 & -1.975 & $0.286 * *$ & $-9.165 *$ & 0.146 & 0.039 & $1.438 * *$ & $-6.370 * *$ & -6.285 & -0.763 \\
\hline \multirow[t]{3}{*}{54} & 23 A x S-19/14 & -0.500 & 0.525 & $0.174 * *$ & -7.940 & -0.804 & -0.043 & $-1.689 * *$ & -1.470 & 3.590 & $-2.850 *$ \\
\hline & S.E sij & 0.820 & 0.987 & 0.051 & 4.380 & 0.582 & 0.271 & 0.387 & 2.107 & 4.797 & 1.149 \\
\hline & S.E sij - sik & 0.820 & 0.987 & 0.051 & 4.380 & 0.582 & 0.271 & 0.387 & 2.107 & 4.797 & 1.149 \\
\hline
\end{tabular}

* and ** Significant at 5 and 1 per cent level, respectively 
The concept of general and specific combining ability as a measure of gene action was proposed by Sprague and Tatum (1942). The general combining ability is an average performance of a line in hybrid combinations. Analysis of combining ability provides guidelines for an early assessment of the relative breeding worth of the parental material. The GCA is attributed to additive genetic effects which is fixable. On the other hand, SCA attributed to non additive gene action may be due to dominance, additive $\mathrm{x}$ dominance and dominance $\mathrm{x}$ dominance or higher order gene interaction and is unfixable. The presence of non additive genotypic variance is the primary justification for initiating the hybrid programme. As grain yield is the most important character in a pearl millet, the parent with high, desirable and significant GCA effects for trait can be selected for use in further breeding programme. The general combining ability effect revealed that, none of the parent showed consistent good combiner for all the characters under study. Similar results were also reported by Bhardwaj et al., (2015) and Dangariya et al., (2009).

In the present investigation the tester, S-19/13 was found good general combiner for six characters viz., grain yield per plant, number of effective tillers per plant, earhead length, earhead girth, 1000 seed weight, harvest index in desired direction followed by line $\mathrm{S}$ 16/769 A, DHLB-23 A and testers S-19/12 for four characters (Table 2.). The line, S16/769 A depicted positive significant GCA effect for six characters viz., earhead length, 1000 seed weight, grain yield per plant, harvest index in desirable direction and for days to $50 \%$ flowering, days to maturity in undesired direction. The line DHLB-23 A had significantly positive GCA effects over only two characters viz., number of effective tillers per plant and grain yield per plant. While, it had significant negative GCA effects over days to $50 \%$ flowering and days to maturity in desired direction with plant height, earhead length, 1000 seed weight and harvest index in undesired direction. Among the 14 parents the line, S-16/760 A, S-16/704 A and tester S19/03, S-19/04, S-19/05, S-19/08, S-19/09 were found poor combiner while, the tester $S$ 19/10 and S-19/14 exhibited their average performance for grain yield per plant.

The estimate of GCA effect also further revealed that, the parental line showing high GCA effect for pearl millet grain yield also exhibited high to average GCA effect for one or more yield components. Among the parents, highest effect for grain yield per plant in S-19/12 was associated with good GCA effect for four characters and poor GCA effects for three characters. Good general combing ability of S-19/11, S-19/13 and S16/769 A for one or more yield attributing characters might have resulted into high combining ability of these parents for grain yield per plant. These parents could therefore be effectively utilized in breeding programme for developing high yielding varieties/hybrids. The GCA effect of parents were positive and significantly associated with their mean values for majority of characters. However, this was not true for all the characters in all the cases, suggesting that inter allelic interaction were important for these complementary epistatic effects. A close relation between parents per se performance and their GCA effects is important in the choice of parents for crossing programme.

The best performing parent may not always be a best general combiner, further, the best general combiner may not always produce best specific combination for all the characters. However, in some cases, high SCA effects of $F_{1}$ hybrids coincide with high GCA effects of the parents. The line, S16/704 A had high per se performance but does not have good GCA for grain yield per 
plant. Similar result reported by Naik et al., (1996) order to show the relationship between per se performance of parents with their GCA effects.

The estimate of SCA effects revealed that, none of the crosses were superior simultaneously for all the characters. As regards to specific combining ability effects nine crosses exhibited significant positive specific combining effects for grain yield per plant. The highest SCA effect for grain yield per plant was exhibited by cross, S-16/704 A x S-19/12 along with superior SCA effect for characters like number of effective tillers per plant, fodder yield per plant, harvest index including grain yield per plant and with average SCA effect for characters days to $50 \%$ flowering, days to maturity, plant height, earhead length, earhead girth, 1000 seed weight in desirable direction followed by $\mathrm{S}$ 16/760 A x S-19/05, DHLB-23 A x S-19/04, S-16/704 A x S-19/13, S-16/769 A x S-19/13, S-16/769 A x S-19/11, S-16/760 A x S-19/03, S-16/704 A x S-19/14, DHLB-23 A x S19/05. Similar results also recorded by Solanki et al., (2017) and Badurkar et al., (2018).

In conclusion, among the best five crosses based on per se performance the crosses, S16/704 A x S-19/12, S-16/704 A x S-19/13 and DHLB-23 A x S-19/04 has poor x good combining parent for grain yield. Positive SCA effects in crosses between poor and good combiners could be ascribed to be better complementation of favourable alleles of parents involved as reported by Badurkar et al., (2018). The hybrids, S-16/769 A x S19/11 and S-16/769 A x S-19/13 had both good combining parents for grain yield per plant. The heterosis in this cross might have resulted from the interaction of dominant gene contributed by both good combining parents as reported by Nandaniya et al., (2016). Thus, the cross with both good general combiner parent (S-16/769 A x S19/11and S-16/769 A x S-19/13) indicating the role of additive $\mathrm{x}$ additive type of gene action could be used in utilization of hybridization programme.

The ranking on the basis of SCA effects was not always reflected by the ranking based on per se performance and crosses showing high mean performance may not always show high SCA effects. The per se performance of the parent was highly associated with their GCA effects. Hence, the choice of best cross combination on the basis of per se performance could be more realistic and useful. Almost identical results have been reported by Solanki et al., (2017), Nandaniya et al., (2016), Dangariya et al., (2009) and Karvar et al., (2017).

\section{References}

Athwal, D.S. (1965). Hybrid Bajra 1 marks a new era. Indian Farming., 15: 6-7.

Badurkar, S. B., Pole, S. P., Toprope, V. N. and Ingle, N. P. (2018). Combining ability for grain yield and its related traits in pearl millet (Pennisetum glaucum L.)

Int.J.Curr.Microbiol.App.Sci., (2018) Special Issue-6: 956-961.

Bhardwaj, R., Kaur, M., Sohu, R. S. and Singh, D. P. (2015). Combining ability studies in pearl millet (Pennisetum glaucum L.). Forage Res., 41(2): 78-84.

Dangariya, C.J., Chotalia, J.M., Savaliya, J.J., Davda, B.K., and Pansuriya, A.G. (2009). Combining ability analysis in pearl millet (Pennisetum glaucum (L) R. Br.). Agric. Sci. Digest., 29(4): 287290.

Karvar, S. H., Pawar, V. Y., and Patil, H. T. (2017). Heterosis and combining ability in pearl millet. Electronic Journal of Plant Breeding, 8 (4): 1197-1215.

Kempthorne, O. (1957). An introduction to 
genetic statistics. John Wiley and Sons. Inc. New York. pp. 458-471.

Lakshmana, D., Biradar, B. D., Madaiah, D. and Jolli, R. B. (2011). Combining ability studies on $\mathrm{A}_{1}$ source of cytoplasmic male sterility system in pearl millet. Indian J. Agric. Res., 45(1): 45-51.

Naik, V., Rvikumar, R. L. and Madhav Rao, T. (1996). Combining ability studies for grain and its components in pearl millet (P. typhoides). Karnataka J. Agri. Sci., 9(4): 635-641.

Nandaniya, K.U., Mungra, K. D., and Sorathiya, J. S. (2018). Assessment of combining ability for yield and micronutrients in pearl millet. Electronic Journal of Plant Breeding,
7(4): 1084-1088.

Patel, B. C., Patel, M. P. and Patel, J. A. (2016A). Combining ability studies for grain yield and its components in pearl millet (Pennisetum glaucum (L) R. Br.). Electronic Journal of Plant Breeding,7(3): 595-601.

Solanki, Kanti Lal., Bhinda, Mahendar Singh., Gupta, P. C., Saini, Harkesh., and Saini, Lipendr Kumar.(2017). Combining ability and gene action studies for grain yield and component characters in pearl millet (Pennisetum glaucum L.) under arid condition of rajasthan. Int. J. Pure App. Biosci., 5(4): 2121-2129.

\section{How to cite this article:}

Patil, S. H., P. B. Wadikar, S. L. Waghmode and Tathe, R. G. 2021. Combining Ability and Gene Action Studies for Grain Yield and its Components in Pearl Millet [Pennisetum glaucum (L.) R. Br.]. Int.J.Curr.Microbiol.App.Sci. 10(01): 2385-2391. doi: https://doi.org/10.20546/ijcmas.2021.1001.277 